\title{
CORRESPONDENCE
}

\section{Respect limits of embryo patents}

In what could be a milestone case, the Court of Justice of the European Communities is expected to clarify and define the term human embryo as used in European patent law within the next few months. But patent law should not be driven solely by the interests of patent holders (Nature 472, 418; 2011).

The environmental group Greenpeace started this court case to obtain clarification of European patent directive 98/44/EC, which prohibits the granting of patents on "uses of human embryos for industrial or commercial purposes" and on "the human body at the various stages of its formation and development".

The European patent granted in 1999 to Austin Smith, Peter Mountford and the University of Edinburgh, UK (EP 0695351; 1999), covered human embryos, embryonic stem cells and their production from human embryos. Opposition from Greenpeace and others, including the German and Dutch governments, caused the European Patent Office (EPO) to revoke large parts of the patent.

In 2008, the EPO decided in another precedent case (G2/06) not to grant patents on human embryonic stem cells produced by the destruction of human embryos. The number of European patent applications in stem-cell research has since increased. We expect the European Court of Justice to make a similar decision to the EPO and think that, in general, stem-cell research will not be affected.

We believe that patents should not encourage the production or destruction of human embryos for commercial use. Before the European patent directive came into force in 1998, the scientific community and the biotechnology industry had lobbied for its approval. Clear ethical limits were a precondition for its adoption by the European Parliament. Science and industry should now respect these limits. Roland Hipp ${ }^{\star}$ Greenpeace, Germany. roland.hipp@greenpeace.de Peter Liese ${ }^{\star}$ Member of European Parliament, Chairman of the European People's Party Working Group on Bioethics. ${ }^{*}$ On behalf of 4 co-signatories. See http://dx.doi.org/10.1038.474036a for a full list of signatories and for a declaration of competing interests.

\section{Cameroon: not ready for REDD+}

Contrary to your implication

(Nature 472, 390; 2011),

the World Bank's policy on

indigenous peoples depends on more than just their consent after consultation.

The charter of our Forest Carbon Partnership Facility (FCPF) makes it clear that World Bank safeguards, which ensure development finance is environmentally and socially sustainable, apply to FCPFfinanced activities. This includes the bank's policy on indigenous peoples: the bank will proceed only with projects supported by affected communities after free, prior and informed consultation.

Regarding Cameroon's REDD+ plan (which goes beyond 'reducing emissions from deforestation and forest degradation' to include conservation and sustainability), the FCPF has not yet disbursed any funds to the country as it still has to draft its national REDD+ plan. It is therefore too early to judge the plan's content or the quality of consultations.

So far, Cameroon has submitted to the FCPF only its initial idea note for the Readiness Preparation Proposal, prepared with the environment ministry (not with the conservation group
WWF, as suggested in your Editorial) in 2008. The FCPF reviewed this document and has advised Cameroon how to achieve adequate consultation during the drafting of the next stage of its national proposal.

Cameroon will therefore not be in a position to present its proposal at this month's meeting of the FCPF participants committee.

Benoît Bosquet FCPF, World Bank, Washington DC, USA. bbosquet@worldbank.org

\section{Cameroon: listening to indigenous peoples}

A report by the Forest Peoples' Programme (FPP) criticizes the REDD forest-emissions reduction process in Cameroon for its perceived lack of measures to protect and benefit forest communities (Nature 472, 390; 2011). It is premature to cry foul at this point as the process has yet to start.

The conservation group WWF and its partners recognize that indigenous and local communities' rights will be strengthened by including them in national REDD programmes, ultimately putting management of their lands back in their hands. Hence a pre-meeting has already been held for indigenous peoples. With its knowledge of social safeguards, the FPP's contribution will be valuable to this process.

The WWF is set to undertake a REDD pilot project in the Ngoyla-Mintom region, where the indigenous Baka people are crucial rights-holders and full participants in determining the future of this 1-million-hectare forest. The WWF believes that such efforts will help to establish successful national REDD programmes and to ensure that the forests on which these communities depend are maintained.
Much work lies ahead to deliver REDD's promises on climate, biodiversity and people's well-being. But it should not be declared a failure before it starts. David Hoyle WWF Cameroon. djhoyle@wwf.panda.org

\section{Population mapping of poor countries}

Global population maps can be valuable for quantifying populations at risk, such as those near nuclear power plants (Nature 472, 400-401; 2011). But the uncertainties inherent in such data sets must be acknowledged. The census data used in map construction for rich countries are recent and detailed. The same is often not true for poorer countries.

For example, Angola's last census was in 1970, broken down into just 18 districts. Estimates of its current total resident population vary from 13.3 million to 19 million, according to the US Census Bureau and the United Nations, respectively. When such outdated and coarse-resolution data are subject to different modelling assumptions by different groups, it can lead to substantially divergent estimates of population distributions and, consequently, populations at risk.

Uncertainties in and between global population maps should be more widely discussed, and a greater effort made to quantify them. Furthermore, spatially referenced demographic data used in map construction are often scattered across national statistical offices and websites. A centralized, open-access, up-to-date database would benefit many fields that rely on population maps, and would require minimal investment. Andrew Tatem University of Florida, USA.

andy.tatem@gmail.com

Catherine Linard University of Oxford, UK. 